\title{
Decolonising the 'Eye' within the 'I' - Heterotopias of Self: An Interdisciplinary Exploration of Visual and Material Relationships among and between Space, Body, Memory, Identity and Place
}

\author{
N. Jade Gibson \\ ORCID iD: https://orcid.org/0000-0002-5282-3047
}

\section{Abstract}

This paper operates in conjunction with the creation of, and responses to, a set of creative works conceptualised by myself, operating together as a research process towards investigating the concept of 'heterotopias of self' in relation to positionality, memory, identity, place, space and body. The creative work is in the form of film pieces, which, respectively, engage with dissociations between social memory and history in Cape Town ('Rootless', Gibson 2013a); the relationship between the gendering of toys, land, war and violence ('War Play', Gibson 2013b); and the projection of ethnic identification in relation to visuality and geographical location ('Wish You Were Here', Gibson 2015').

Keywords: Heterotopias of Self, Mono-disciplinary approaches, Ethnic identification, Art, Film, Literature, Visual Anthropology, Identity, Practicebased Research, Embodiment, Body, Gender, Space, Culture, Violence, History, Geography, Autobiography

https://objects2015.wordpress.com/2015/06/18/wish-you-were-here-theartist-as-ethnographic-object/ 


\section{Introduction}

This article works in conjunction with the creation of, and responses to, a set of creative works conceptualised by myself, operating together as a research process towards investigating the concept of 'heterotopias of self' in relation to positionality, memory, identity, place, space and body. The creative work is in the form of film pieces, which, respectively, engage with dissociations between social memory and history in Cape Town ('Rootless', Gibson 2013a); the relationship between the gendering of toys, land, war and violence ('War Play, Gibson 2013b'); and the projection of ethnic identification in relation to visuality and geographical location ('Wish You Were Here', Gibson 2015²).

The films and article bring together concepts of self, memory and visual materiality in relation to historical and personal dissociations and displacements within society, to challenge mono-disciplinary approaches, and thus open up questions concerning interdisciplinary approaches, in particular to explore how often invisible structures of power within social and urban spaces infuse what is 'seen' and 'not seen' in the 'making visible' of selves.

The combined works become vehicles for theoretical exploration, as a means of considering alternative ways of engaging with multiple and seemingly disparate disciplines, from medical - as in memory, body and trauma - to gendered, psychological, conceptual and spatial perceptions of the self's interrelationships with society, to examine the 'Eye' within the 'I' within different modes of embodied representation.

Despite their flows of constant renewal and interaction (Mbembe \&Nuttall 2004), urban spaces are fraught with difficulties. Frictions often emerge disparate gaps and clashes between communities, contestations over spaces and histories, and disputes over rights to spaces of the city.

South Africa, for example, has undergone xenophobic attacks (Nyamnjoh 2007; Neocosmos 2006; Hadland 2008; Dodson 2010; Tafira 2011; Solomon \& Kosaka 2013; Mlambo 2019; Marumo et al. 2010; Solomon 2019; Asuelime

2 https://objects2015.wordpress.com/2015/06/18/wish-you-were-here-theartist-as-ethnographic-object/ 
2020; Chenzi 2020) while violence in general - including gender violence and abuse (Boonzaier \& de la Rey 2003; Gqola 2007; Abrahams et al. 2009; Muluneh et al. 2019) - continues to infuse city spaces.

Spaces of memorialisation such as the Rhodes statue have been interrogated and removed alongside \#RhodesMustFall and the ensuing \#FeesMustFall protests (Nyamnjoh 2016; Griffiths 2019; Murris 2016; Naicker 2016; Pillay 2016; Ndlovu 2017; Bosch 2016; Chaudhuri 2016), alongside calls for decolonising tertiary education institutions in South Africa (Mbembe 2016; Becker 2017; Muswede 2017; Fomunyam \& Teferra 2017; Xaba 2017; Duku \& Salami 2017; Mampane et al. 2018; Mahabeer 2018; Sathorar \& Geduld 2018; Shefer 2019), while sites of slave memorialisation remain relatively invisible (see later regarding Prestwich Street - Rassool 2011; Shepherd 2007; Finnegan et al. 2011).

More recently, Cape Town has seen the rise of a 'Coloured nationalism' (Jacobs 2018; IOL News 2020). Tied up with these interactions are disputes around notions of identity; their histories, their visibilities, and their negotiation, in what Hall (1990) terms is a fluctuating production, 'never complete, always in process, and always constituted within, not outside, representation'. (222). Key to such processes are issues of inclusion and exclusion - a sense of belonging, access and voice, in which notions of culture, gender and racism intersect (Maart 2004; 2014a; 2014b).

The spaces we live within, are not neutral, but are imbued with power relations, social perceptions, and bodily interrelationships (De Certeau 1984; Foucault 1986; Soja 1989, 1996; Lovell 1998; Butler 1990; Lefebvre 1991; Nast \& Pile 1998; Mbembe \& Nuttall 2004; Pile 2005), within sites and desires of the imagination which infuse scripts of being, and 'being seen' to the extent that, 'we do not live in a homogenised empty space, but on the contrary, in a space thoroughly imbued with quantities and perhaps thoroughly fantasmatic as well' (Foucault 1986:23), 'an expression of an aesthetic vision' and 'a site of fantasy, desire and imagination', (Mbembe \& Nuttall, 2004: 354 - 355) rather than 'nothing but the spatial embodiment of unequal economic relations and coercive and segregationist policies' (ibid.: 353), a 'phantasmagoric' space of dreams, hauntings, fantasies and desires beyond the visible and tangible - a 'psychogeography' (Pile 2005), and 'an oeuvre, closer to a work of art than to 


\section{N. Jade Gibson}

a simple material product ... a 'production and reproduction of human beings by human beings, rather than a production of objects' (Lefebvre 1991: 101).

There is a concern that, 'the particular ways in which spatial relationships come together to make bodies and places, through the body and through places, needs to be exemplified, demonstrated and clarified, in places, through the body' (Nast \& Pile 1998: 4), in which urban spaces operate a 'conjunction of seemingly endless possibilities of remaking' where 'bodies constantly are 'on the line' to affect and be affected, 'delivered up' to specific terrain and possibilities of recognition or coalescence' (Simone 2004: 9).

This article incorporates an exploration of three short art films by the author, incorporating a praxis-based research approach, in an exploration of the interwoven-ness of the above issues in relation to representation, to open up questions around 'seeing', and 'being seen' by the author - ('Rootless', see Gibson 2013a); engaging with dissociations between social memory and history in Cape Town; 'War Play' (Gibson 2013b), examining the relationship between the gendering of toys, land, war and violence; and 'Wish You Were Here' (Gibson 2015) ${ }^{3}$, exploring the projection of ethnic identification in relation to visuality and geographical location. Each film engages with a different aspect of embodied experience - at times seemingly surrealistic, at others, disturbing, and also drawing on the auto-ethnographic. Previous articles (Gibson 2013a; Gibson 2013b; Gibson 2015) have described, to varying extents, aspects of the creation process of these films. This discussion also draws on the concept of heterotopia in relation to the concept of self - as dissociative ${ }^{4}$ yet embodied aspects of selves that form part of the negotiation of self with society.

3 https://objects2015.wordpress.com/2015/06/18/wish-you-were-here-theartist-as-ethnographic-object/

${ }^{4}$ In this sense, I use 'dissociation' as a metaphorical term, implying its psychiatric definition as the 'separation of normally related mental processes, resulting in one group functioning independently from the rest, leading in extreme cases to disorders such as multiple personality' (Oxforddictionaries.com, acc. 090815). 'Dissociation' is a medical term now used in preference to 'multiple personality disorder' as the many selves that are presented are seen to link on a deeper plane and although performed 


\section{Decolonising the 'Eye' within the 'I' - Heterotopias of Self}

\section{Rootless}
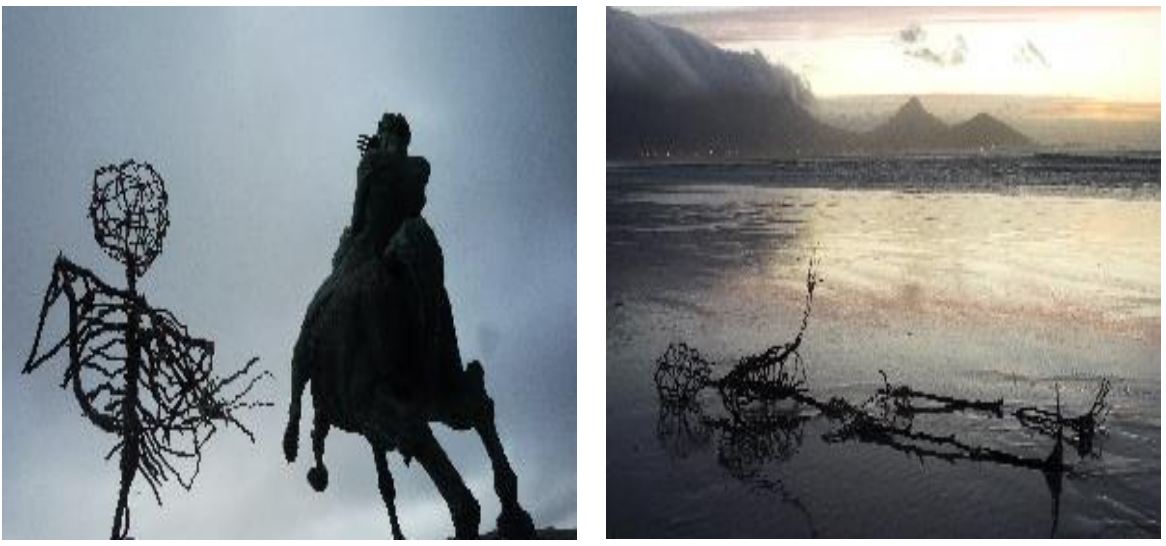

Figure 1: Rootless, Rhodes Memorial Figure 2: Rootless, Blouberg Beach

The first film, Rootless ${ }^{5}$, involves a life-sized skeleton, created from twigs, filmed as if on a oneday tourist visit to Cape Town, touring sites imbued with memory and history but which also, when juxtaposed with the skeleton - which operates like a life-size puppet - evoke aspects of loss and historical dispossession in relation to land, memorialisation, space and heritage. These spaces are nature reserves; Rhodes Memorial; Prestwich Memorial - the site of storage of over 1000 exhumed skeletons, assumed to have mostly been previous slaves, from a graveyard uncovered during building work near Prestwich Street in central Cape Town (see Shepherd

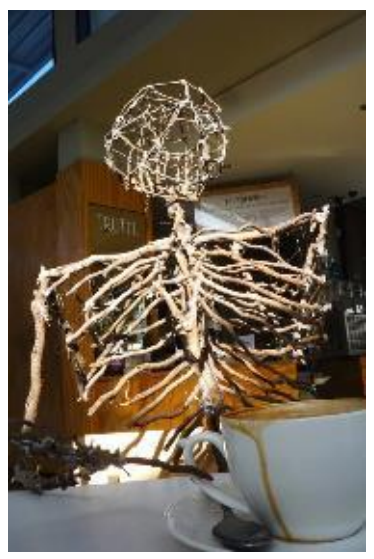

separately, are understood to be integrated within the same person. Interestingly, Krüger (2020) has recently argued for culture to be foregrounded in studies of dissociation.

${ }^{5}$ Created in part-collaboration with artist Kitty Dorje (camera and editing) and Meghna Singh (editing). 


\section{N. Jade Gibson}

2007; Rassool 2011) - Iziko Museum, which at the time was undergoing restitution processes concerning Khoisan remains kept in the museum archive (see Legassick \& Rassool 2000); and Blouberg Beach, with its view of Table Mountain. The issues the skeleton raised are described in more detail in Gibson (2013a) particularly in relation to my previous experience as a medical student, and questions in relation to human remains.

On a poetic and aesthetic level, however, the film also evokes a sense of loss and dispossession - combined with a poem I created based on the concept of loss, and a very effective music track created especially for the film by a local composer/ musician (Dino Chapman Van Rooyen). Effectively, there is a sense of the loss of history and memory - evoked by the familiar figure of the skeleton and its association with the graveyard - already a heterotopic space described by Foucault (1986) - but which the viewer also identifies with, through travelling with the skeleton from frame to frame. The film has subsequently been used as part of District Six Museum's commemorative 'Slave Walk' at night in the memory of slaves of the Cape, projected onto the wall of a historic city building as part of a walk through the city, thus contributing to a sense of the phantasmagoric 'haunting' of city spaces as one moves through them, described by Pile (2005) which, for me, was its perfect viewing location, one which evokes Ingold's (1993) claim that 'To perceive the landscape is... to carry out an act of remembrance, and remembering is not so much a matter of calling up an internal image, stored in the mind, as of engaging perceptually with an environment that is itself pregnant with the past' (152f).

Interestingly, people in Cape Town who see the film often connect it with their own personal sense of dispossession too - often describing this as a 'loss' of ancestry, history and living spaces under forced removals during apartheid, along with a consequent sense of loss of 'self'. This is particularly enabled by the skeleton being a non-gendered, non-racialised, ageless and voiceless yet embodied object, facilitating the self-identification of the viewer, as it glides past Rhodes Memorial and looks down at the view of the city the bust of Rhodes 'sees', is served coffee at the commercial café which masks the mausoleum Prestwich Memorial that holds the unnamed remains of the poor and slaves in boxes in a room at the back, and swings merrily before Iziko, where the museum's windows appear like eyes looking through the skeleton's head. 


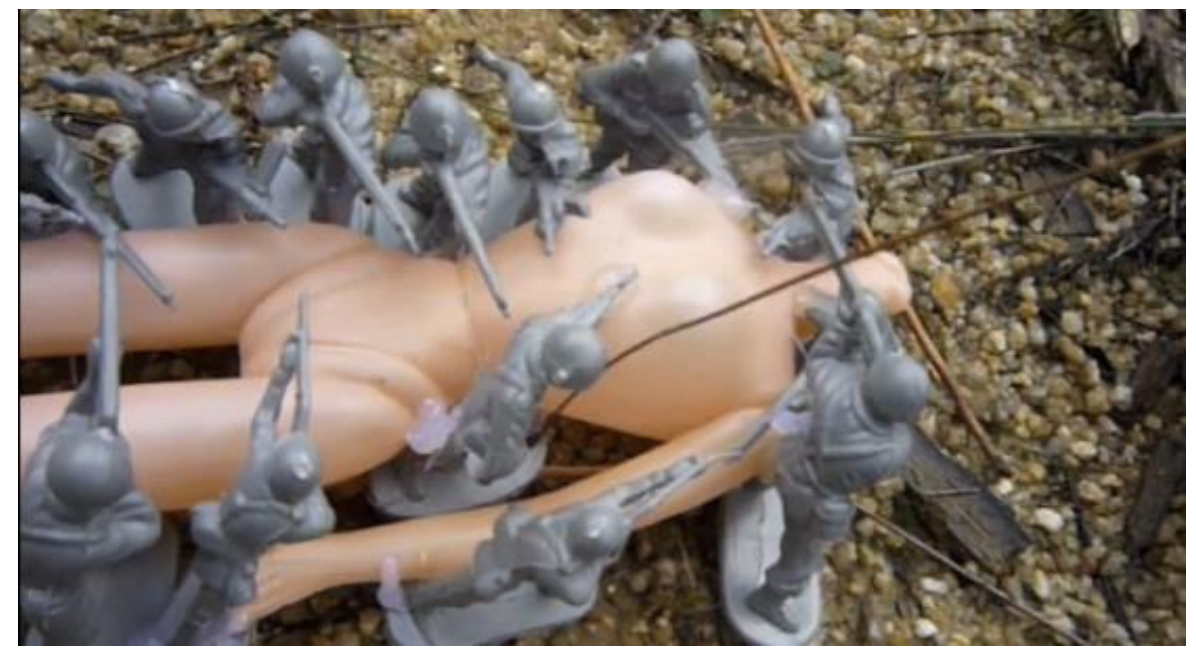

War Play - 'No Man's Land'

\section{War Play}

In the film War Play ${ }^{6}$, toys of childhood typically associated with gender girl dolls, male action figurines, plastic army soldiers and guns readily available in South African stores - are assembled, dismembered, reassembled and juxtaposed to explore the associations between embodied notions of masculinity and femininity inculcated and engaged with in childhood, and male violence in relation to women's bodies, land and war in adult life. In the film, toy soldiers and action figurines appear in juxtaposition with often headless or silenced naked female doll figures that operate sometimes as landscape to fight over, at other times as a 'trophy', or in one case, a female figure whose body is made up of toy soldiers, appears to be shooting herself.

In other scenes, the female figures hold guns, as if in self-protection. The works were created and filmed at a Thupelo Art Workshop in the Wellington landscape in South Africa (Gibson 2013b), as if randomly found while crawling through the bush. Background music was composed using the

${ }^{6}$ Conceptualisation, mise-en-scène, filming and directing by myself, editing assistance from Jarrett Erasmus. 


\section{N. Jade Gibson}

nursery rhyme, 'Three Blind Mice' with sounds suggesting a battlefield, and the voice of a young boy. ${ }^{7}$ As the origin and making of this film is described briefly in a previous article (Gibson 2013b), I focus here on embodied aspects of the film in relation to the formation of identity in its construction as a 'story of self' (Sacks 1995) shaped by memory, and performed, enacted and felt as a construction through an experiential, embodied and sensory mode of operandi, 'concerned with, and assembled from, sensory and experiential fragments' (Seremetakis 1994: 4). Gender is a continually reiterated practice, sedimented in the body to the extent that it appears naturalised (Butler 1990). But where does this naturalisation start, and how does it then become articulated later in its intersections with violence, race, geography and space?

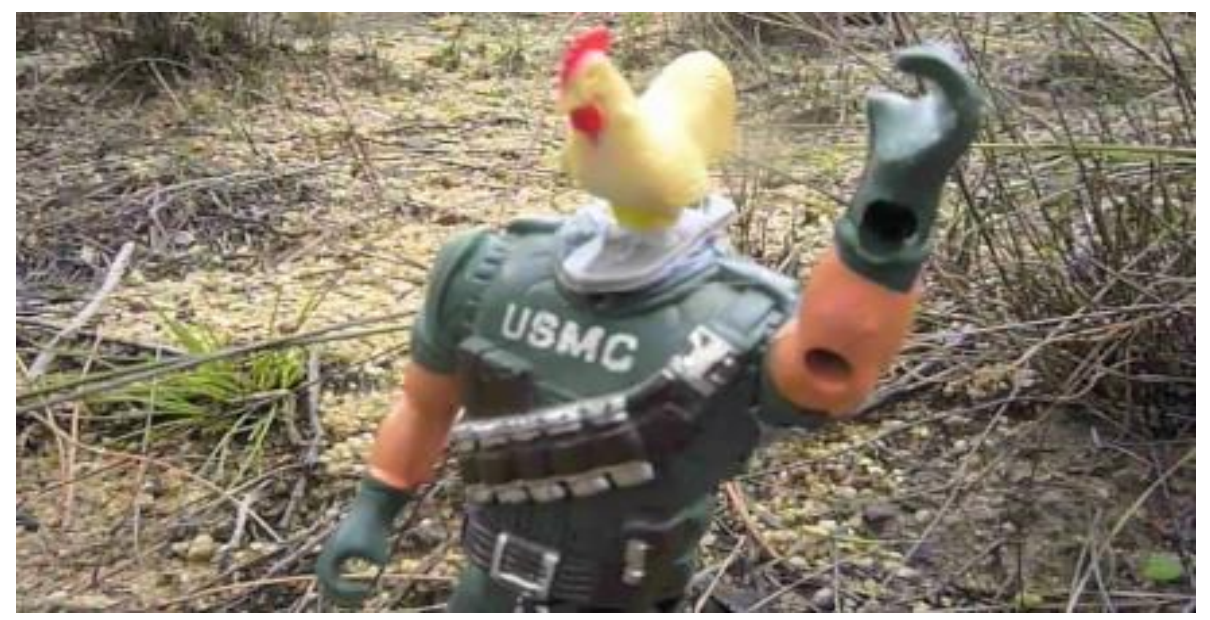

\section{War Play - 'Chicken-Head Man'}

Interestingly, when War Play was shown in the CAS gallery exhibition 'Body: Object: Corpse', deliberately on a small television in a child-sized room ${ }^{8}$ women responded very strongly to the images. One declared emphatically, 'yes, we should take up weapons against men!' Others responded by describing the vulnerability they felt as women, particularly in relation to how men treat

${ }^{7}$ Composed by Mijaou Blech and with the voice of Bailey Blech.
${ }^{8}$ Curated by Meghna Singh in the exhibition 'Body: Object: Corpse'. 
them and their susceptibly to gender violence in South Africa, which has a history of gender violence from colonialism through apartheid to the present day, and currently has among the highest domestic abuse and rape statistics in the world (Maart 2004, Maart et al. 2014; Boonzaier \& de la Rey 2003; Gqola 2007; Abrahams et al. 2009; Hutchinson 2013). As Gqola (2007) puts it, 'We know that today women do not feel safe in the streets and homes of South Africa, that women's bodies are seen as accessible for consumption - touching, raping, kidnapping, commenting on, grabbing, twisting, beating, burning, maiming - and control, that women are denied the very freedom that 'empowerment' suggests, the very freedom the Constitution protects' (120), and goes on to describe how 'apartheid capitalised on the physical violence of contestation through the militaristic control as well as the structural violence of the economy ... this high militarisation could only take on gendered forms and play itself out along sharply gendered lines... Given its pervasiveness, it finds expression in the academic, business and non-governmental sectors, in culture, language and entertainment and government institutions' (113f).

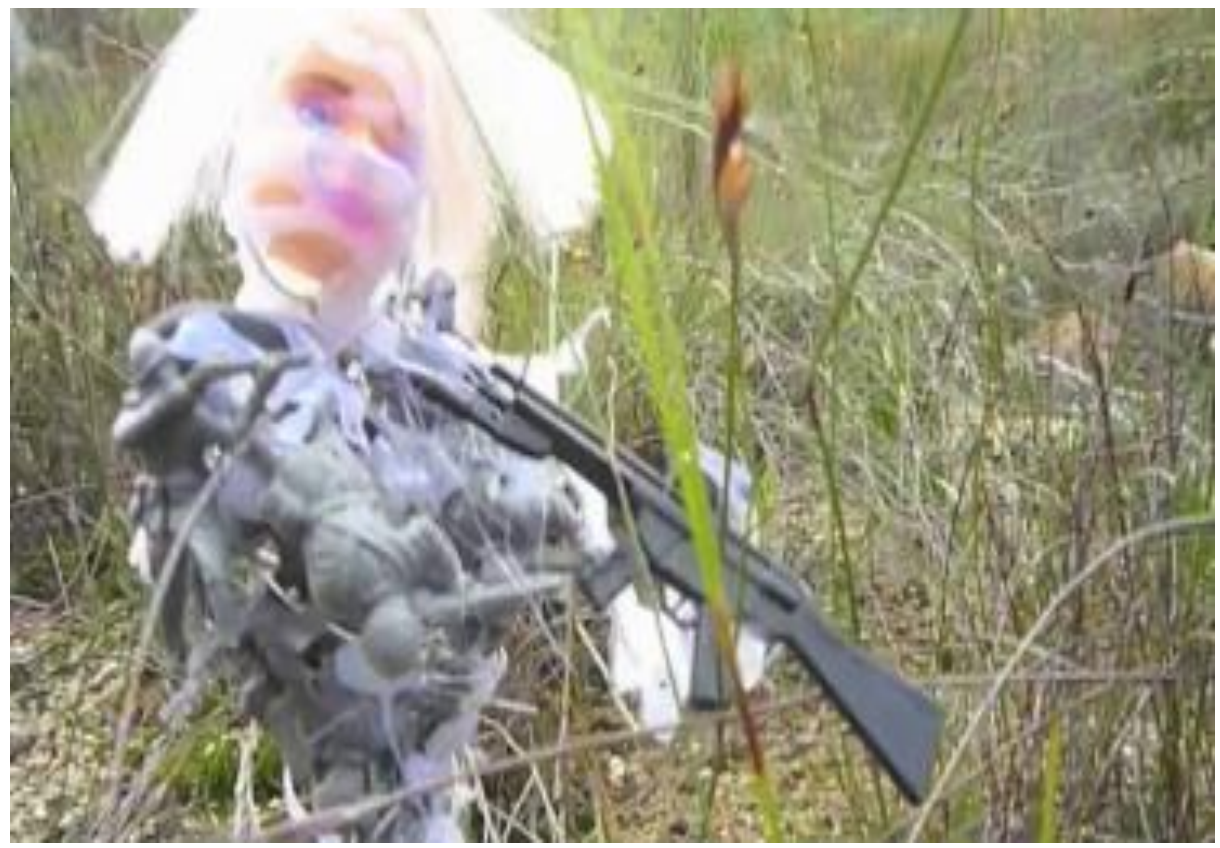

War Play - 'Plastic Surgery Woman' 


\section{N. Jade Gibson}

It is interesting how the responses were often highly visceral - in the case of women, a sense of expression of their own vulnerability and fears in relation to the objectification of their bodies, and the need to protect or defend them; and in the case of men, at times an expression concerning the uncomfortableness of what, in the observations I made, they associated the images with pornography, along with the violence of the hypermasculinity that the toys of their childhood suggested ${ }^{9}$.

Men also commented on the film's similarity to video games, in which the camera crawled through the undergrowth in a forest landscape, as if aiming a gun at each figure it came across and seemed to respond to what they saw as the overt sexuality of the images.

War Play also subliminally questions how the performance of masculinity in a militarised society might erupt in extreme violence including the abuse of women, often in the form of rape $^{10}$ as a key mechanism of power over the vanquished in the face of brute force, and in the sexualised, gendered expression of force, juxtaposing the unstoppable super-hero of male invincibility versus the objectified visualised image of accessible girl dolls ${ }^{11}$.

The toys of childhood in War Play visually expose the intersections of constructions of masculinity with militarised violence for boys, even prior to the institutional frameworks, playgrounds and societies which are 'constituted by violent interaction in their very fabric' (Gqola 2007: 114).

Through juxtaposing and combining gendered toys, the film consequently evokes links between the 'male' toys given to boys, expression of violence over land and ownership, including of women's bodies, even as spoils of war. Yet these toys also evoke utopias - expressions of ultimate desires - male power, invincibility and physicality, and the desire of women to look appealing yet their vulnerability in becoming objects of sexual objectification.

9 The soundtrack, by musician/ composer Mijanou Blech, was based on the children's song, 'Three Blind Mice' as an underlying auditory motif for the film.

${ }^{10}$ This does not exclude male rape as an expression of power in war.

${ }^{11}$ Notably, 'white' dolls, are easiest to obtain cheaply in South Africa. 
Intersectionalities of race and gender are also apparent in the ready availability of dolls that, notably in a South African context, are fair-skinned ${ }^{12}$ and would inculcate a racialised 'difference' and utopian desire of 'Whiteness' for local children 'of colour' who play with them. Consequently, War Play connects the disconnected; brings to awareness those dissociated elements within the gendered self that extremes of human behaviour become evident within - the brutality of violence, the racialised divides of the gendered every day, the imaginaries of childhood; and enactments of militarised male violence - that play out in the adulthood of society ${ }^{13}$.

\section{Wish You Were Here}

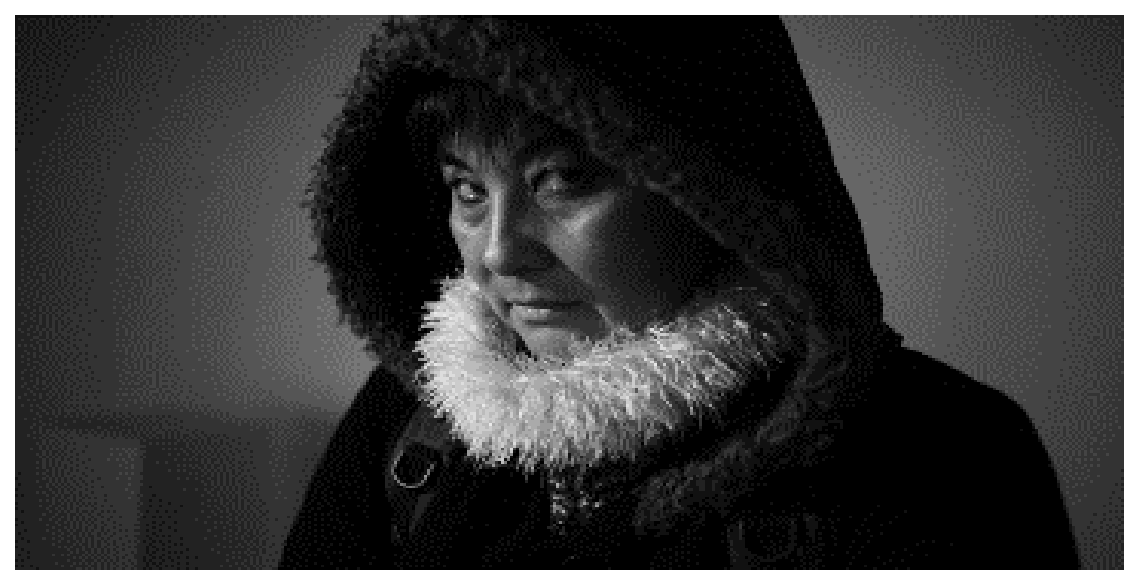

\section{Wish You Were Here - Film Still 'Not Inuit'}

The film, Wish You Were Here, is an exploration of another aspect of identity; the ethnic localisation of self in space and place. In this case, the film draws

${ }^{12}$ In the shop, housed in a small shopping mall in Wellington from which they were obtained, there were no dolls 'of colour' available.

${ }^{13}$ Hutchinson (2013) for example, sees parallels and draws attention to enactments of violence in times of conflict and dispute in contemporary South Africa, as a consequence of South Africa's history as a militarised state in the past. 


\section{N. Jade Gibson}

from personal experience, as someone of mixed ancestral origins - as far as I know, Filipino, Scottish, Irish and Spanish - in relation to how others have ethnically identified me over the years ${ }^{14}$ despite the fact that my identity does not typically fit into a 'category', particularly standard 'ethnic category' boxes one ticks on forms.

Narratives of these mis-identifications in people's efforts to 'locate' me as from different global spaces are presented as if in a black and white 'silent movie' - mimicking Robert J. Flaherty's classic Nanook of the North 1922 ethnographic film depicting the Inuit, for which I have repeatedly been mistaken.

These multiple identities and 'emplacements' projected by others- as seemingly from 'everywhere' - Inuit/Chinese/Uzbekistani/ Peruvian/Native American/Japanese/Thai/Malaysian but interestingly not as European - even at one point being congratulated by a Chinese lady as having the 'eye operation' (Kaw 1993; Aquino 2017; Nguyen et al. 2009; Ouellette 2009) to look more Western - explode the nature of the idiosyncrasy and constructedness of stereotyped racial identities and their intersections with geographical space.

Casting myself as an 'ethnographic art object', and in collaboration with cinematographer Gareth Jones as cameraman, I play out these different ethnicities through reconstructions in my own contemporary clothes to emulate the poses of anthropological and tourist images of the past and present. The soundtrack is mostly segments of Nanook of the North soundtrack played backwards - suggesting the reversal of time, and its flattening through the spaces of ethnic categorisation, in an exploration of where these might come from.

The power of the camera as 'gaze' is also evoked, as I move from plinth (as a museum object), to interior, to outdoors.

${ }^{14}$ See conference blog entry, Gibson (2015).

https://objects2015.wordpress.com/2015/06/18/wish-you-were-here-theartist-as-ethnographic-object/ 
The story is told using a selection of autobiographical experiences over my life, included as written text in the 'silent movie' style, followed by the images as juxtapositions, while I remain muted. ${ }^{15}$

Some of the quotations from the film are:

I am in a shopping mall in a poncho. A woman runs up to me. 'Oh, you're Peruvian, she says. 'How lovely, I got back from Peru yesterday'.

'We thought you were Native American', some anthropologists tell me at a conference.

I am in a museum. A woman comes up to me. 'Oh, you speak English, I thought you were from my village. I'm from Uzbekistan, she says'. An old man refuses to serve me at a vegetable stall. 'I was in a Prisoner of War Camp', he says. 'I don't serve the Japanese'... 'But I'm not Japanese', I say... 'You look Japanese', he says. I won't serve you'. '*\&\%*\$*!,' say men to me in salsa clubs. 'Oh, don't you speak Thail Filipino? Malaysian? It means 'I love you'. I learnt it on holiday in a bar'.

I am in Mozambique and the village children follow me around shouting 'Jackie Chan, Jackie Chan'.

'In this country we have very strict security regulations', says the customs official in Heathrow [International Airport, United Kingdom ].... 'I am from this country', I say.

I come back to the 'I' within the 'eye' here. Is the gaze I project myself within that of the subjectivity of myself, or the objectivity of the outsider gazing in? In our social interactions, and engagements with the world, it is difficult to step outside of these external representations, as projections of how the world has categorised ourselves and others over historical time, particularly so with the history of a colonial science and ethnic 'stereotypes' that site the body's phrenology, skin colour and hair, as a representation of personhood.

The intersectionality of this with gender, sexuality and geography is evident; as someone who enjoys salsa dance, men in salsa venues in the past have

${ }^{15}$ See Gibson (2015) for more detailed information on constructing the piece. 


\section{N. Jade Gibson}

sometimes approached, talking slowly evidently to make sure I can understand their English. Their patronisingly gentle tones are as if directed to a child, no doubt drawing on their experience of the portrayal of Asian women as childlike, passive and willing to please (Wang 2012; Shim 1998) as exemplified in Hollywood films and other forms of media of the 'Oriental fantasy' from the period of 16-year old Afong Moy, the first recorded Chinese woman exhibited in America, in New York and Brooklyn Museums, with fourinch-long slippers on bound feet (Wang 2012 ${ }^{16}$, and no doubt which the 'bar girls' in East Asian tourist venues play into as equivalent exhibits, for the exploitative desires of male consumption. At the same time, in the film, I quote from a 19th century children's book, 'A Peep at the World and a Picture of some of its inhabitants' which in its very brief discussion of China, emphasises the very small bound feet of Chinese women.

In the film, I deliberately contrast this quote with myself sitting upright on a plinth, with a cap and high-necked, dark belted jacket, which is suggestive of a uniformed photograph of a woman from Communist China; then continue with the fact that Mozambican village children identified me as Jackie Chan, with pseudo poses of myself in the film with martial arts poses with a ponytail ${ }^{17}$.

The film was an expression of curiosity, and an attempt to understand what others might be 'seeing' when they projected their assumptions and my ethnic 'phenotype' onto me; an ironic 'projecting back', utilising only my own day clothes and minor props. Much of the suggestibility came from my drawing on 'tourist' and old ethnographic photographs from the different parts of the world I had been identified as, and merely positioning myself in similar bodily stances; such as stroking a cat in my dressing gown in the same pose I had seen a geisha lighting the cigar of a male tourist. In being none of these 'identifications' culturally, the film ends with the officious 'white' United Kingdom (UK) Heathrow International Airport official telling me the rules of 'his' country, which I have to tell him I was also born in, and am consequently

16 This was followed shortly after by the second Chinese exhibit at the circus of P.T. Barnum, bringing 20000 spectators in only six days (Prasso 2005; quoted in Wang 2017).

${ }^{17}$ See Gibson (2015) for image. 
a national of, as much as him. In my mind, these images become resources, repeated time and time again throughout history, and becoming part of a cultural subconscious, drawing from the ever-pervasive media stereotypes and simulated tourist 'encounters' with manufactured ethnic stereotypes at tourist venues. At the same time, they reinforce a geographical stereotype amplifying the link between 'the geography of the world and the geography of the imagination' (Wang 2017:195). The fact that I was also identified in London as Uzbekistani by an Uzbekistani villager perhaps also shows the role that desire plays, possibly in the expression of an immigrant in London to connect with an image of home.

The bigger question might lie with who is projecting onto who, and to what purpose, and the role that memory, history and imagery plays within these. On a more ominous note, I was refused to be served at a market stall by a man who had been in a Japanese prisoner of war camp because he decided I looked Japanese. This also foreshadows the idea of being identified as a 'type', regardless of one's own cultural, social or historical associations, at its worst in the form of xenophobia, racial prejudice and ethnic genocides that permeate the earth.

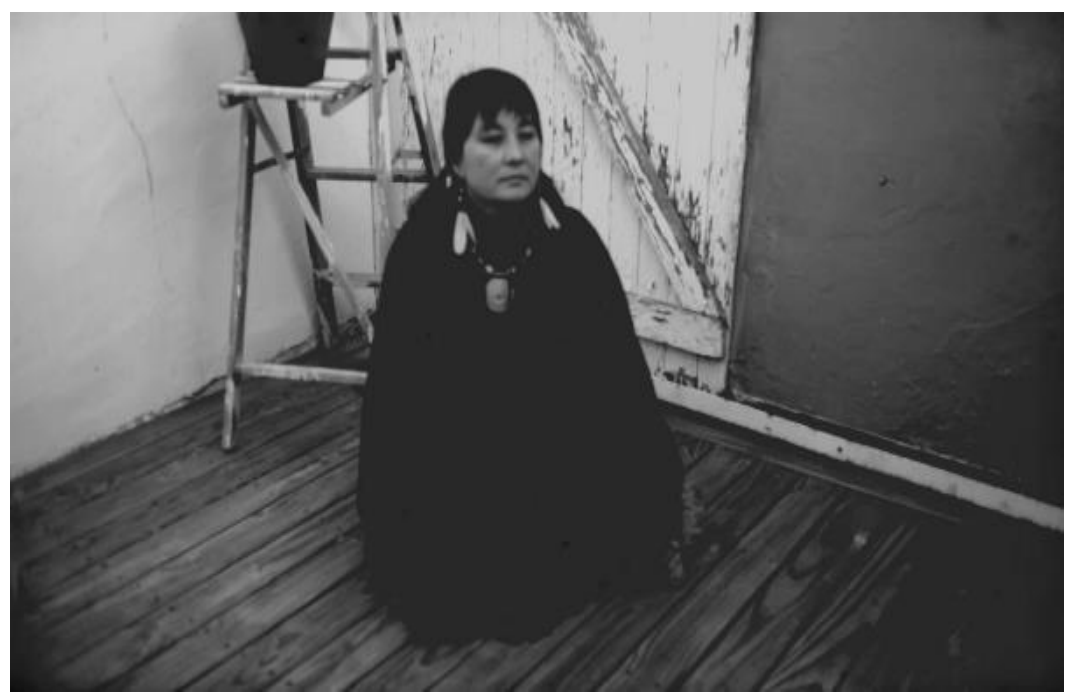

Wish You Were Here - Not Peruvian/ Native American 


\section{N. Jade Gibson}

The film also suggests how media, tourist and ethnographic images from the past and present constantly situate the body in - often seemingly timeless spaces of 'otherness' - in its exoticisation, rejection, acceptance and objectification - and to what extent the body negotiates its existence and selfidentity amongst the impositions or assumptions of others.

The intersectionality ${ }^{18}$ of these negotiations played out in irony, were also apparent when I offered myself as a 'toy' to be dressed up by visitors at Greatmore Studios Art gallery in Cape Town at the 'Till it Breaks' exhibitions in 2012, where visitors dressed me in my own clothes and could create their own 'photograph' alongside the film playing on a screen to the side, with an anonymous hand-drawn landscape background and pot plant.

Here they constructed 'the gaze' and imagination took riot. Some slipped into enacting childhood games; hunting polar bears as an 'Eskimo' (their words); or pretending they were on holiday; or making me 'pretty' as an imagined geisha. Others claimed affinity; a woman from Delhi, India, declared I looked like a North Indian woman and dressed me likewise, and a Palestinian living in Cape Town decided I looked 'typically Cape Malay' ${ }^{19}$, created a headscarf for me and posed beside me.

In these 'makings' of ethnicity, I was attempting to understand the fallacy of the 'constructedness' of a 'racialised' or 'ethnicised' identity stereotype, as well as the stories such projections cannot tell, of the individual subjected to them. At times, the projections of others resonated with the perspective of the paradigm of a historical 'cultural gaze' that constructed me, and by playfully constructing myself as the 'art object', the irony resonates with Maart's words,

We are not artists, we are simply what art or artists sometimes represent ... if Black people or people of colour come into focus or appear on the canvas, it is as the Coloured subject of the White gaze the slave, emancipated slave, exotic, trivialised, creature, or object as the backdrop representing time and place - in other words, servitude and subordination (2004: 3).

${ }^{18}$ See Crenshaw (1991).

${ }^{19} \mathrm{I}$ have often been told this in Cape Town. 
The film has since 'travelled' to Cambridge in the UK (Gibson 2015) and to a conference in Paris at the request of an attending academic. It is interesting that, in Europe, the question was raised by attendees that I might, possibly, be re-ethnicising myself and playing into racial stereotypes by depicting myself in such ways. Interesting, also, persons of colour in Cape Town who have seen the film have generally laughed in collusion at the recognition of the many subjectivities they themselves feel objectified by. My personal response is why, if I choose to wear my own poncho, or clothes, or stand in a particular way, or lean against a wall as if attending a salsa club, should I be re-ethnicising anyone, or become an ethnic 'type' in other's eyes, as I am merely representing myself?

Perhaps we need to dig deeper; to unpack and uncover the plethora of representations to which we are all subject, and to ask how we might rethink, reconceptualise, and re-represent them, to get to a basic humanity of where we wish to go, and be, to look for the 'I' within the 'Eye' that constructs all of us, if we really believe in a world that collectively claims to work together against genocides, poverty, and racial prejudice.

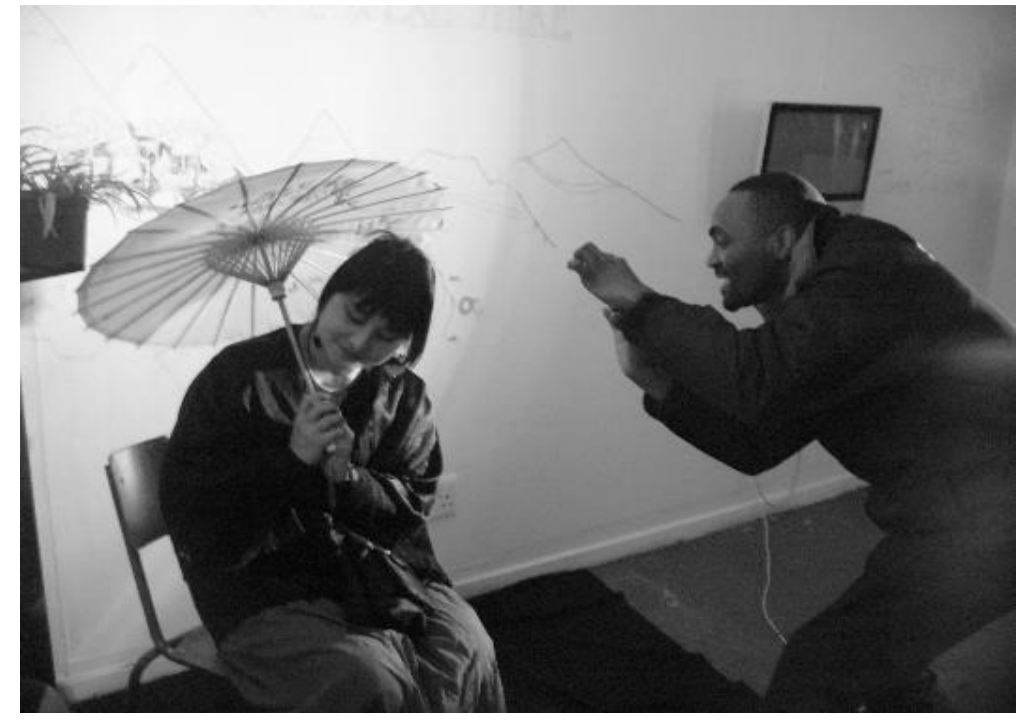

'Till it Breaks' Exhibition 2013, Greatmore Studios - 'Not in Japan' 


\section{Conclusion, and Non-Conclusiveness: The 'Eye' within the ' $I$ '}

These three films, in association with this article, have explored, through primarily visual means, the material aspects - the embodied negotiation - in the construction of identity and self. It is interesting to note that, in all three films, the body itself - the skeleton, the reconstructed girl and body toys; and the body as 'ethnographic art object' - is silenced, despite the soundtrack and written narratives, none have an audible voice, thus emphasising their embodied-ness and the extent to which these are unarticulated. How then, do these social 'bodies' of self - often difficult to articulate or contest, silenced by society, or even unrealised by persons who engage with them, exist and intersect within the corpus of the social geographies and city spaces on lives within? Theorists such as Taylor $(2006 ; 2007)$ extend the material socialisation of the body to suggest that 'critical attention to repertoires of lived behaviour might illuminate very different versions of past events, enable alternative mappings, and generate other models of scholarly interaction' (2007: 1418) in her argument that studies of ritual and social performances provide insights into histories that have been 'written out' of more formal sources.

However, the negotiations of the body are complex and play out differently in different spaces - as memory, identity, gender, history, community and self; as well as through dis-articulation and dissociations - that of the erasure of history and what is memorialised in Rootless; the gendered desires reflected in boy and girl toys played out in challenging and sometimes destructively extreme scenarios in War Play; and also in Wish You Were Here, in relation to the assumptions, desires, and impositions of others, who play out our identities for us. These to me are the heterotopias of self - the spaces of 'otherness', 'dissociation' and 'difference' within one's own experiential, remembering and enacting body, that one might occupy, yet feel a discomfort in belonging within, or which only become apparent in brief moments of reversal or possibly insight, aptly, and beautifully, summed up in the following excerpt from Foucault, in his description of a mirror, as both a utopia and a heterotopia,

... I see myself where I am not, in an unreal, virtual space that opens up behind the surface; I am over there, there where I am not, a sort of shadow that gives my own visibility to myself, that enables me to see myself there where I am absent: such is the utopia of the mirror. But it 
is also a heterotopia, in so far as the mirror does not exist in reality, where it exerts a sort of counteraction on the position that I occupy. From the standpoint of the mirror I discover my absence from the place where I am since I see myself over there. Starting from this gaze that is, as it were, directed toward me, from the ground of this virtual space that is on the other side of the glass, I come back toward myself; I begin again to direct my eyes toward myself and to reconstitute myself there where I am. The mirror functions as a heterotopia in this respect: it makes this place that I occupy at the moment when I look at myself in the glass at once absolutely real, connected with all the space that surrounds it, and absolutely unreal, since in order to be perceived it has to pass through this virtual point which is over there (Foucault 1986:24).

Despite the fact that the films do incorporate aspects of utopian desire - the tourist on holiday; the desirability of 'gendered' ideal bodies; the exotic, often vicarious 'elsewheres' engaged with in our own connections with others - I focus on the films as primarily depicting heterotopias of self - in that the films are more likely to be viewed as focusing on moments of deviance or crisis the dead, unacknowledged histories; dispossession; gender violence; the idealisation of the hyper-masculinisation and brutality of war; and imposed notions of race and locality. How, then, does one reconnect and integrate the body, within its web of negotiated, sometimes challenged, interrelationships in city spaces, to find points of cohesion and the acceptance of multiplicities within the constructed nature of self, rather than the disjuncture of different heterotopias within the in-between spaces of personhood.

Calls for decolonisation extend beyond an academic syllabus, a written text, a rethinking of history; they extend to a reshaping of experience, of lived memory and embodied interaction, the search for the 'I' within the 'Eye'. All three films indicate, to some extent, traumas on and of the body - even if not immediately apparent - the infliction of power relations onto selves as the ethnic or gendered 'other'; the dissociation of ownership over memory and history; Rhodes Memorial 'psychogeographically' jostling with the suggested image of exhumed slave skeletons in central Cape Town - these are all felt traumas that may exist consciously or unconsciously within those who sense their dislocation and dissociation from society. Furthermore, how does one engage theoretically with such 'heterotopias of self', in their disconnect 


\section{N. Jade Gibson}

between the 'here' and 'there', 'past' and 'present', and 'reconnect' individuals, within the many negotiations, conscious and unconscious, that they encounter as they 'walk' their phantasmagoric, heterotopic, sometimes traumatic and other times illusionary 'elsewheres', not just through the street and walkways but also museums; hospitals, play areas, shopping malls and other material landscapes of cities that 'are not simply material or lived spaces - they are also spaces of the imagination and spaces of representation' (Bridge \& Watson 2004: 7). When 'Rootless' was used for the District Six Slave Commemoration walk in 2012, projected onto the walls of the Slave Lodge, did it help 'close' those gaps or dissociations? Does 'War Play' enable a reconnect between those images of femininity and masculinity inscribed from early childhood; an embodied familiarity with their presence juxtaposed against the unfamiliarity of their associated social violence?; does 'Wish You Were Here' enable a reconnect with the disciplines of a connected humanity with the 'divide and prosper' tool not of apartheid only, but the act of the modernist project of colonisation in its working of history? Recently, I have engaged with the creative text - a literary novel, Glowfly Dance (Gibson 2015), encompassing a memoir/autobiography, documenting childhood experiences of domestic violence, from personal experience. The book has been accredited by the South African Department of Education as useful for education on domestic violence, and has been used in diverse university courses, from Medical Humanities to Anthropology, to Psychology, Literary and Gender Studies. The story encompasses themes of identity, childhood, girlhood and emerging womanhood, migration, domestic violence, abuse, abduction, and the devastating impact of intimate partner femicide on children.

It was written to make people feel, in the voice of the child, and its impact is designed to occur through the embodied and emotional impact of reading the story, yet other activities - public and educational talks, workshops and media events - are what brings it to public awareness. Interestingly, as a speaker, I find myself 'performed' on various 'trauma' rather than 'thriver' panels, in auto-ethnographic documentation (University College of London, University of Cape Town) seminars, even on a men's indaba (discussion) for ex-offenders. ${ }^{20}$ The book has taken me on a series of journeys and encounters that themselves would require extended contextualisation and discussion in an exploration of the complex platforms for, and giving voice to,

${ }^{20}$ Glowfly Dance also appeals to men who were children of domestic violence 
'representations', and 'performances' of domestic violence in society by those who tell their story. Interestingly, in its production, the publisher's representative initially produced a book cover with a Caucasian girl on the front. 'The cover looks great', I said. 'But the girl's eyes have to be slanted. Racism is part of the book'. 'The readers won't mind', said the representative. 'The book constantly refers to slanted eyes', I said. 'Can't we find an image of an Asian girl?' 'That will be too difficult', said the publisher. 'You wouldn't accept it if it was the other way around', I said. After some insistence, the representative 'saw the light' and agreed to Photoshop a photograph of my own eyes into the image of the girl on the cover and, finally, I had my own eyes within the ' $I$ '.

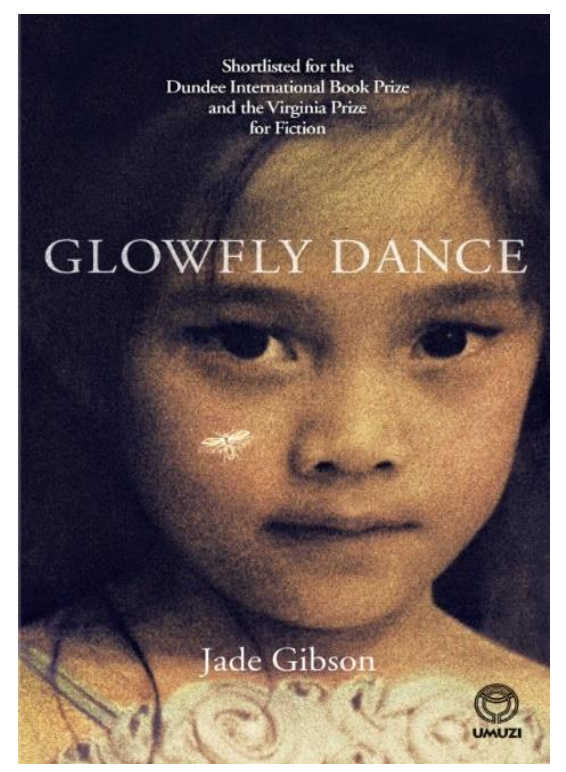

The aim of this article is to establish a sense of the complexity of the self's embodied negotiation of spaces and society, and the multiple frames and environments in which the embodied self, often on an unconscious or articulated level, is produced - and furthermore, dissociations in its sense of production or expression as an identity, and as a consequence, raise questions for further engagement and raise a challenge. How does one move from heterotopias of excluding 'others' (even aspects of our own selves) to inclusive multitopias of self, in past and present?

\section{'Glowfly Dance' front cover}

How does one create a mobile, flowing, effective urban space that incorporates multiple histories and engagements, gives space, voice and visibility to the economically and/or socially dispossessed, deal with xenophobia and displacements through and in relation to the material spaces and images that 


\section{N. Jade Gibson}

people engage with and are subject to? What makes a formerly inaccessible space become accessible? How does one create changes within the status quo when embodied aspects of self may be buried or dissociated to some or full extent from consciousness? And where does the emotional and emotive lie within this; is there a theoretical approach for what is felt rather than spoken, to unpack what might be taken as 'understood 'within a perceived racial, gendered and social stasis that may have set in, within a space and time of institutional and structural change?

Is there a way to research and rework these relationships; either by exposing them through juxtaposition, making visible the invisible seams of South African society, one that previously operated through the categorisation, spatial and psychological exclusion of bodies? What is the habitus (Bourdieu 1977) of such a society and how does one gain theoretical insight?

Instead of building along the same gridlines, how might one might one rework referents of inclusion rather than exclusion, in relation to the materiality and spaces that bodies inhabit from childhood onwards; and in recognition of the multiple ways in which selves engage with the world through practice, in order to integrate alternative modes of living and connection for a future city, through spaces understood as embodied, physical and imaginal? Ideally, I would present this article with the films, as they work in conjunction, to work in an interdisciplinary mode across text, emotion, vision and as an embodied evisceration of the objectified objectivity of a racialised and gendered past. Perhaps it is only when one connects disciplines to find alternative modes of interdisciplinary engagement that one might find alternative research approaches and theoretical languages for engaging with some of the above questions.

The role of interdisciplinary centres at universities is growing worldwide. Such centres require a means of working across disciplines, to establish a new or common language of engagement, rather than the disengagement and specialisation of disciplines as discrete parallels behind interdisciplinary facades. Such an approach might involve moving beyond a unilateral thinking towards a polysemic inquiry that maintains academic rigour yet incorporates the material and physical, as a poesis of engagement concerned with the evocation and construction of materiality, place and space. Otherwise, despite a rhetoric of inclusion and multiplicity, one might exclude rather than include; re-traumatise rather than amend, and continue power discrepancies rather than equalise, repeating past frameworks of restraint. 
This then is an article, and yet not a article, incorporating films and stories in its presentation, to engage thinking on multiple levels and open up interdisci-plinary engagement, utilising tools such as creative process, history, auto-ethnography, gender and place. It invokes a need for further research into embodied modes of inclusion and exclusion, trauma, and the construction and negotiation of identities, in relation to the flows and constraints of urban life.

The presentation works spatially, bodily, and materially, in relation to disconnects or 'heterotopias' of self, to present a research approach that I hope is felt and experienced as much as merely written, and to provide insight into how one might, returning to Foucault (1986) 'discover my absence from the place where I am' and, in turn, 'begin again to direct my eyes toward myself and to reconstitute myself there where I am' (24), to unpack the 'Eye' within the collective 'I' that subsumes selves within representational practices and absences that fail to see who and what is really there.

\section{References}

Abrahams, N., R. Jewkes, L.J. Martin, S. Mathews, L. Vetten \& C. Lombard 2009. Mortality of Women from Intimate Partner Violence in South Africa: A National Epidemiological Study. Violence and Victims 24, 4. https://doi.org/10.1891/0886-6708.24.4.546

PMid:19694357

Aquino, Y.S.J. 2017; 'Big eye' Surgery: The Ethics of Medicalizing Asian Features. Theoretical Medicine and Bioethics. Springer. https://doi.org/10.1007/s11017-017-9395-y [Acc. 08/2020]

Asuelime, R.A. 2020. Ubuntu and Xenophobia Incongruities and the 2019 South African Election Impetus. Gender \& Behaviour 18, 1: 14621 14630.

Becker, A. 2017. Rage, Loss and Other Footpaths: Subjectification, Decolonisation and Transformation in Higher Education. Transformation in Higher Education 2,23.

https://doi.org/10.4102/the.v2i0.23

Boonzaier, F. \& C. de la Rey 2003. 'He's a Man, and I'm a Woman': Cultural Constructions of Masculinity and Femininity in South African Women's Narratives of Violence. Violence against Women 9, 8, August: 1003-1029. https://doi.org/10.1177/1077801203255133 
Bourdieu, P. 1977. Outline for a Theory of Practice. London: Cambridge University Press. https://doi.org/10.1017/CBO9780511812507

Bosch, T. 2016. Twitter Activism and Youth in South Africa: The Case of \#RhodesMustFall. Information, Communication \& Society

https://doi.org/10.1080/1369118X.2016.1162829

Bridge, G. \& S. Watson (eds.). 2004. A Companion to the City. Oxford: Blackwell Publishing.

Butler, J. 1990. Gender Trouble: Feminism and the Subversion of Identity. New York. Routledge

Crenshaw, K. 1991. Mapping the Margins: Intersectionality, Identity Politics, and Violence against Women of Color. Stanford Law Review 43, 6, July: 1241 - 1299. https://doi.org/10.2307/1229039

Chenzi, V. 2020. Fake News, Social Media and Xenophobia in South Africa. African Identities. $\quad$ https://doi.org/10.1080/14725843.2020.1804321 (Accessed in August 2020.)

Chaudhuri, A. 2016. The Real Meaning of Rhodes Must Fall. The Guardian Wednesday 16 March 2016.

De Certeau, M.M. 1984. The Practice of Everyday Life. Berkeley: University of California Press.

Dodson, B. 2010. Locating Xenophobia: Debate, Discourse, and Everyday Experience in Cape Town, South Africa. Africa Today 56, 3, Special Issue: Africa's Spaces of Exclusion, Spring 2010: 2 - 22. Available at: https://www.jstor.org/stable/10.2979/aft.2010.56.3.2

(Accessed in August 2020.).

Duku, N. \& I.A. Salami 2017. The Relevance of the School Governance Body to the Effective Decolonisation of Education in South Africa. Perspectives in Education 35,2: 112 - 125.

http://dx.doi.org/10.18820/2519593X/pie.v35i2.9

Flaherty, R.J. 1922. Nanook of the North. Film (75 minutes). [DVD] United States.

Finnegan, E., T. Hart \& D. Halkett 2011. The 'Informal' Burial Ground at Prestwich Street, Cape Town. The South African Archaeological Bulletin December, 66, 194: 136 - 148.

http://www.jstor.com/stable/23631416 (Accessed in August 2020.)

Fomunyam, K.G. \& D. Teferra 2017. Curriculum Responsiveness within the Context of Decolonisation in South African Higher Education. Perspectives in Education 35,2: 196 - 207. 
http://dx.doi.org/10.18820/2519593X/pie.v35i2.15 (Accessed in August 2020.)

Foucault, M. 1986. Of Other Spaces. Diacritics 16,1,Spring: 22 - 27; 24 -25. https://doi.org/10.2307/464648

Gibson, N.J. 2013a. Skeletal (In)-Visibilities in the City - 'Rootless': A Video

Sculptural Response to the Disconnected in Cape Town. South African

Theatre Journal 26, 02: 1 - 21

https://doi.org/10.1080/10137548.2012.839097

Gibson, N.J. 2013b. Visual Ethnographies of Displacement and Violence:

Land(e)scapes in Artists' Works at Thupelo Artists' Workshop, Wellington, South Africa 2012. Special issue: Revisiting the Ethnographic Turn in Contemporary Art. Critical Arts: South - North Cultural and Media Studies 27,5.

https://doi.org/10.1080/02560046.2013.855519

Gibson, N.J. 2013c. The 'Great Walk and More' - Thupelo Artists' Workshop 2010: Performing Community through the Visual Arts in Cape Town, South Africa. Anthrovision 1.1. Visual Anthropology Network of the European Association of Social Anthropologists (VANEASA).

http://anthrovision.revues.org/538.acc. 120813

Gibson, N.J. 2015. Wish You Were Here: The Artist as Ethnographic Object. CRASSH 'Objects in Motion' Conference blog, June 2015. Cambridge University, UK. https://objects2015.wordpress.com/2015/06/18/wishyou-were-here-the-artist-as-ethnographic-object/

Gibson, N.J. 2015. Glowfly Dance. Penguin Random House and Umuzi.

Gqola, P.D. 2007. How the 'Cult of Femininity' and Violent Masculinities

Support Endemic Gender Based Violence in Contemporary South Africa.

African Identities 5,1:111 - 124.

https://doi.org/10.1080/14725840701253894;

https://doi.org/10.1080/ (Accessed in June 2020.)

Griffiths, D. 2019. \#FeesMustFall and the Decolonised University in South Africa: Tensions and Opportunities in a Globalising World. International Journal of Educational Research 94: 143 - 149.

https://doi.org/10.1016/j.ijer.2019.01.004

Hadland, A. 2008. Violence and Xenophobia in South Africa: Developing Consensus, Moving to Action. Human Sciences Research Council.

Hall, S. 1990. Cultural Identity and Diaspora. In Rutherford, J. (ed.): Identity: Community, Culture, Difference. London: Lawrence and Wishart. 
Hutchinson, Y. 2013. South African Performance and Archives of Memory. Manchester, UK and New York, USA: Manchester University Press.

Ingold, T. 1993. The Temporality of the Landscape. World Archaeology 25, 2. Conceptions of Time and Ancient Society. Routledge.

https://doi.org/10.1080/00438243.1993.9980235

IOL News, Staff Reporter, 28 July 2020. Cape no longer 'Coloured' and Protests not the Answer, says Activist Group. Lawrence and Wishart. Jacobs, S. 13 June 2018. The Limits of Coloured Nationalism. Mail and

Guardian. https://mg.co.za/article/2018-08-13-00- the-limits-ofcoloured-nationalism/

Kaw, E. 1993. Medicalization of Racial Features: Asian American Women and Cosmetic Surgery. Medical Anthropology Quarterly March, New Series, 7, 1: $74-89$.

http://www.jstor.com/stable/649247

(Accessed in August 2020.)

https://doi.org/10.1525/maq.1993.7.1.02a00050

Krüger, C. 2020. Culture, Trauma and Dissociation: A Broadening Perspective for our Field. Journal of Trauma \& Dissociation 21,1: 1 - 13.

https://doi.org/10.1080/15299732.2020.1675134 (Accessed in August 2020.)

Lovell, N. 1998. Locality and Belonging. London, New York: Routledge.

Lefebvre H. [1974] 1991. The Production of Space. Oxford, UK, and Cambridge, MA: Blackwell.

Legassick, M. \& C. Rassool 2000. Skeletons in the Cupboard: South African Museums and the Trade in Human Remains 1907 - 1917. Cape Town, South Africa: South African Museums.

Maart, R. 2004. The White Screen, The White Canvas. The Ontarian January 2004. Guelph, Ontario.

Maart, R. 2014. Philosophy Born of Massacres. Marikana, the Theatre of Cruelty: The Killing of the 'Kaffir'. Acta Academia 46,4: 1 - 28. https://journals.ufs.ac.za/index.php/aa/article/view/1470/1447

Maart, R. 2014b. Race and Pedagogical Practices: When Race Takes Centre Stage in Philosophy. Hypatia 29,1: 205 - 220.

https://doi.org/10.1111/hypa.12076

Maart, R., I. Mafatshe \& Z. Hlope 2014. Black Feminism in the 1980s. Agenda 28,1: 110 - 118 .

https://doi.org/10.1080/10130950.2014.883706 
Mahabeer, P. 2018. Curriculum Decision-makers on Decolonising the Teacher Education Curriculum. South African Journal of Education 38, 4, November: 1-12. https://doi.org/10.15700/saje.v38n4a1705

Mampane, R.M., M.F. Omidire \& F.R. Aluko 2018. Decolonising Higher Education in Africa: Arriving at a Global Solution. South African Journal of Education 38, 4, November: 1 - 9.

https://doi.org/10.15700/saje.v38n4a1636

Marumo, P.O., M. Chikale \& A. Mothelesi 2010. Xenophobia Attack and Development: A Discourse in South Africa. African Renaissance Special Issue March: 185 - 198.

https://doi.org/10.31920/2516-5305/2019/s1n1a9

Mbembe, A. \& S. Nuttall 2004. Writing the World from an African Metropolis.

Public Culture 16, 3, Fall: 347 - 372.

https://doi.org/10.1215/08992363-16-3-347

Mbembe, A-J. 2016. Decolonizing the University: New Directions. Arts \& Humanities in Higher Education 15, 1: 29 - 45.

https://doi.org/10.1177/1474022215618513

Mlambo, D.N. 2019. A South African Perspective on Immigrants and Xenophobia in Post-1994 South Africa. African Renaissance 16, 4, December: 53 - 67. https://doi.org/10.31920/2516-5305/2019/16n4a3

Muluneh, M.D., V. Stulz, L. Francis \& K. Agho 2019. Gender Based Violence against Women in Sub-Saharan Africa: A Systematic Review and MetaAnalysis of Cross-Sectional Studies. International Journal of Environmental Research and Public Health 17: 903.

https://doi.org/10.3390/ijerph17030903 (Accessed in August 2020.)

Murris, K. 2016. Rhodes Must Fall: A Posthumanist Orientation to Decolonising Higher Education Institutions. South African Journal of Higher Education 3: 274 - 294.

http://dx.doi.org/10.20853/30-3-653 Volume 30.

Muswede, T. 2017. Colonial Legacies and the Decolonisation Discourse in Post-apartheid South Africa. A Reflective Analysis of Student Activism in Higher Education. African Journal of Public Affairs 9, 5, January: 200 -210 .

Naicker, C. 2016. From Marikana to \#feesmustfall: The Praxis of Popular Politics in South Africa. Urbanisation 1, 1: 53 - 61.

https://doi.org/10.1177/2455747116640434

(Accessed in August 2020.) 
Nast, H.J. \& S. Pile (eds.). 1998. Places through the Body. London, New York: Routledge.

Ndlovu, M. 2017. Fees Must Fall: A Nuanced Observation of the University of Cape Town, 2015 - 2016. Agenda 31, 3 - 4: 127 - 137.

https://doi.org/10.1080/10130950.2017.1402489

Neocosmos, M. 2006. From 'Foreign Natives' to 'Native Foreigners': Explaining Xenophobia in Post-apartheid South Africa. CODESRIA Monograph Series.

Nguyen, M.Q., P.W. Hsu \& T.A. Dinh 2009. Asian Blepharoplasty. Seminars in Plastic Surgery. Cosmetic Surgery in the Ethnic Population: Special Considerations and Procedures Aug 23, 3: 185 - 197.

https://doi.org/10.1055/s-0029-1224798 (Accessed in August 2020.)

PMid:20676313 PMCid:PMC2884917

Nyamnjoh, F.B. 2007. From Bounded to Flexible Citizenship: Lessons from Africa. Citizenship Studies 11, 1, February.

http://dx.doi.org/10.1080/13621020601099880

Nyamnjoh, F.B. 2016. Rhodes Must Fall: Nibbling at Resilient Colonialism in

South Africa. Bamenda: Langaa Research and Publishing Common Initiative Group.

Ouellette, A. 2009. Eyes Wide Open: Surgery to Westernize the Eyes of an Asian Child. The Hastings Center Report 39, 1, Jan. - Feb.: 15 - 18. https://www.jstor.org/stable/25548347 (Accessed in August 2020.) https://doi.org/10.1353/hcr.0.0098

PMid:19213188

Pile, S. 2005. Real Cities: Modernity, Space and the Phantasmagorias of City Life. London, Thousand Oaks, New Delhi: Sage Publishers.

Pillay, S.R. 2016. Silence is Violence: (Critical) Psychology in an Era of

Rhodes Must Fall and Fees Must Fall. South African Journal of Psychology 46, 2: 155 - 159. https://doi.org/10.1177/0081246316636766 Prasso, S. 2005. The Asian Mystique. New York: Public Affairs.

Rassool, C. 2011. Bone Memory and the Disciplines of the Dead: Human Remains, Transitional Justice and Heritage Transformation in South Africa. Paper presented at Centre for Humanities Research seminar, University of the Western Cape, 2011. (Permission obtained.). Publication in German. Rassool, C. Knochengedächtnis. Menschliche Überreste, Recht und National Heritage in Südafrika. In Sommer, M. \& G. Krueger (Hersg.): Biohistorische Anthropologie: Knochen, Korper und DNA in 
Decolonising the 'Eye' within the 'I' - Heterotopias of Self

Erinnerungskulturen. Berlin: Kadmos.

Sacks, O. [1985] 1995. A Matter of Identity. (Excerpt taken from The Man who

Mistook his Wife for a Hat, 1985.) In Raimes, A. (ed.): Identities:

Readings from Contemporary Culture. United States: Houghton Miffin

Company.

Sathorar, H. \& D. Geduld 2018. Towards Decolonising Teacher Education:

Reimagining the Relationship between Theory and Praxis. South African Journal of Education 38, 4, November: 1 - 12.

https://doi.org/10.15700/saje.v38n4a1714

Seremetakis, N.C. 1994. The Senses Still: Perceptions and Memory as Material Culture in Modernity. Chicago, IL: University of Chicago Press. Shepherd, N. 2007. Archaeology Dreaming: Post-apartheid Urban Imaginaries and the Bones of the Prestwich Street Dead. Journal of Urban Social Archaeology 7, February: 3 - 28.

https://doi.org/10.1177/1469605307067842

Solomon, H. \& H. Kosaka 2013. Xenophobia in South Africa: Reflections,

Narratives and Recommendations. Southern African Peace and Security

Studies 2, 2.

Soja, E.W. 1989. Postmodern Geographies: The Reassertion of Space in

Critical Social Theory. London: Verso.

Soja, E.W. 1996. Thirdspace - Journeys to Los Angeles and Other Real-andImagined Places. Oxford, UK, and Cambridge, MA: Blackwell.

Shefer, T. \& S.R. Munt 2019. Editorial: Feminist Politics of Shame. A Feminist

Politics of Shame: Shame and its Contested Possibilities. Feminism and Psychology 29, 2: 145 - 156.

Shim, D. 1998. From Yellow Peril through Model Minority to Renewed Yellow Peril. Journal of Communication Inquiry 22, 4, October: 385 409. https://www.researchgate.net/publication/249734709;

https://doi.org/10.1177/0196859998022004004

Simone, A.M. 2004. For the City yet to Come: Changing African Life in Four Cities. Durham and London: Duke University Press. https://doi.org/10.1515/9780822386247

Solomon, R. 2019. Xenophobic Violence and the Ambivalence of Citizenship in Post-apartheid South Africa. Citizenship Studies 23, 2: 156 - 171. https://doi.org/10.1080/13621025.2019.1584158

Tafira, K. 2011. Is Xenophobia Racism? Anthropology Southern Africa 34, 3 \& 4: $114-121$. 
https://doi.org/10.1080/23323256.2011.11500015

Taylor, D. 2006. Performance and/ as History. TDR (The Drama Review) 50, 1, : 67 - 86. https://doi.org/10.1162/dram.2006.50.1.67

Taylor, D. 2007. Remapping Genre through Performance: From 'American' to 'Hemispheric' Studies. PMLA (Publication of the Modern Language Association of America) 122, 5: 1416 - 1430.

https://doi.org/10.1632/pmla.2007.122.5.1416

Wang, H. 2012. Portrayals of Chinese Women's Images in Hollywood. Mainstream Films - An Analysis of Four Representative Films of Different Periods. Intercultural Communication Studies XXI, 3: 82 - 92. Xaba, W. 2017. Challenging Fanon: A Black Radical Feminist Perspective on Violence and the Fees Must Fall Movement. Agenda 31, 3 - 4: 96 - 104. https://doi.org/10.1080/10130950.2017.1392786 (Accessed in August 2020.)

\author{
N. Jade Gibson \\ Research Fellow \\ Centre for African Studies \\ University of Cape Town \\ jadegibson@gmail.com
}

